\title{
Application of cephalometry to prosthetic dentistry - literature review
}

\section{Zastosowanie cefalometrii w protetyce stomatologicznej - przegląd piśmiennictwa}

\author{
Marcel Czajkowski ${ }^{1}$, Joanna Kuć2, Teresa Sierpińska ${ }^{2}$ \\ ${ }^{1}$ Indywidualna Specjalistyczna Praktyka Stomatologiczna w Bydgoszczy \\ Private Dental Specialist Practice \\ ${ }^{2}$ Zakład Protetyki Stomatologicznej, Uniwersytet Medyczny w Białymstoku \\ Department of Prosthodontics, University of Bialystok \\ Head: dr hab. n.med. Teresa Sierpińska
}

KEY WORDS:

cephalometry, prosthodontics, dental prostheses, dental occlusion, occlusal plane

\section{Summary}

Introduction. Cephalometry has been a diagnostic medical tool since 1934. Its first application was the assessment of facial part of the skull growth pattern. Nowadays it is used in diagnosis of malocclusion and orthodontic, surgical or prosthetic treatment planning. It is also commonly used in bone age assessment. The purpose of cephalometry in prosthetic dentistry is the estimation of vertical dimension of occlusion, soft tissue profile recording, the occlusal plane orientation and determination of condylar or anterior guidance.

Aim of the study. To present the clinical purpose of cephalometry in prosthetic dentistry.

Material and methods. The literature review was carried out using PubMed with the following MeSH terms: cephalometry, prosthodontics, dental prostheses, dental occlusion, vertical dimension of occlusion and occlusal plane. Nineteen publications that met the aforementioned criteria and a few publications out of the search results were qualified for the review.

Results. The literature review revealed a

\section{HASŁA INDEKSOWE:}

cefalometria, protetyka stomatologiczna, protezy stomatologiczne, zwarcie, płaszczyzna protetyczna

\section{Streszczenie}

Wprowadzenie. Cefalometria jest radiologiczna metoda diagnostyczna stosowana $w$ medycynie od 1934 roku. Początkowo wykorzystywana byta jedynie do analizy wzorców wzrostu twarzowej części czaszki. Obecnie jej zastosowanie poszerzyło się o diagnostykę wad zgryzu oraz planowanie leczenia ortodontycznego, chirurgicznego i protetycznego. Coraz szerzej stosowana jest do radiologicznej oceny wieku kostnego pacjentów. Protetyka stomatologiczna wykorzystuje analize zdjęć cefalometrycznych do wyznaczania pionowego wymiaru zwarcia, określania przebiegu płaszczyzny protetycznej, oceny profilu tkanek miękkich, określania kąta nachylenia drogi stawowej i prowadzenia siecznego.

Cel pracy. Celem pracy byto przedstawienie klinicznego zastosowania cefalometrii w protetyce stomatologicznej na podstawie przegladu piśmiennictwa.

Material i metody. Dokonano przegladu piśmiennictwa wykorzystując baze PubMed, używając słów kluczowych wg Medical Subject Headings: cephalometry, prosthodontics, dental 
multitude of applications of cephalometry to prosthetics. The aim of cephalometry appliance presentation was to determine its value as a diagnostic method in prosthetic treatment.

Conclusion. Scientists use many of cephalometric analysis methods. Research groups are rather small and endemic. That is why comparative studies are hard to carry out. The purpose of this literature review is to present the range and direction of studies conducted in this field up to the present day.

\section{Introduction}

A word "cephalon" comes from Ancient Greek, where "kephale" means head. Nowadays the term is employed to describe the head part of an arthropod (cephalon) or the study of human head measurements (cephalometry).

At the very beginning cephalometry was widely used for facial part of the skull growth pattern assessment. Its indications have become wider over time. Nowadays it is used in malocclusion diagnosis, bone age assessment and orthodontic, surgical or prosthetic treatment planning. Proper interpretation of cephalograms is possible due to cephalometric analysis methods. The main rule of such analysis is to assign landmarks, lines and gnatho- or craniometric angles to obtain patient's skull and bones measurements. Each analysis has its own interpretation key and possible deviations. prostheses, dental occlusion, vertical dimension of occlusion, occlusal plane. Do przegladu zakwalifikowano 19 prac spetniajacych powyższe kryteria oraz piśmiennictwo specjalistyczne nie objęte powyższa formuta wyszukiwania.

Wyniki. Analizowana literatura ukazała mnogość sposobów wykorzystania cefalometrii w protetyce stomatologicznej. Przedstawienie zastosowań tej metody diagnostyki miało na celu określenie jej przydatności w leczeniu pacjentów protetycznych.

Podsumowanie. Autorzy badań nad stosowaniem cefalometrii $w$ protetyce stomatologicznej nie korzystaja z jednego wzorca analizy cefalometrycznej. Poddani badaniom pacjenci stanowia często mato liczne i endemiczne grupy badawcze. Wynikaja stad trudności $w$ analizie porównawczej wyników badań z poszczególnych ośrodków. Poniższe opracowanie ma charakter przegladowy i ma za zadanie przedstawić zakres i kierunek prowadzonych dotad na tym polu badań.

\section{Wstęp}

Słowo „,ephalon” wywodzi się z języka starogreckiego, w którym „kephale” oznacza głowa. Współcześnie słowo to używane jest do określenia głowowej części stawonogów (cephalon) oraz nauki zajmującej się analizą pomiarów głowy człowieka (cefalometria).

Cefalometria początkowo służyła ortopedom szczękowym do analizy wzorców wzrostu twarzowej części czaszki. Z biegiem czasu wskazania do jej stosowania zaczęły się poszerzać. Obecnie wykorzystywana jest do diagnostyki wad zgryzu, planowania leczenia ortodontycznego, chirurgicznego i protetycznego oraz radiologicznej oceny wieku kostnego pacjentów. Prawidłowa interpretacja cefalometrycznych obrazów rentgenowskich możliwa jest dzięki zastosowaniu odpowiedniego systemu ich analizy. W uproszczeniu proces ten polega na wyznaczaniu punktów, linii oraz kątów gnato- i 
The most widely used analyses were developed by Ricketts, McNamara, Bjork, Jarabak and others. ${ }^{1,3,4}$

Cephalometric radiography, introduced by Hofrath and Broadbent in 1934, is a basic cephalometry tool nowadays. Radiographs are taken by the use of a specially designed head holder called cephalostat. This utility fixes patient's head with ear rods inserted into external auditory canals and a nasal positioner adjusted to the bridge of the nose. Ear rods are equipped with radiopaque elements helping to mainten the proper head position. X-ray impenetrable ruler submerged in the head positioner facilitates linear measurements during the cephalometric analysis. The cephalostat helps to perform a comparative analysis of subsequent or previous films. It also ensures a constant picture magnification ratio (5-10\%, depending on the type of apparatus). Thanks to divergent X-ray beam, the objects situated close to the sensor present less image magnification than the distant ones. The picture enlargement may come up to $20 \%$, depending on the distance. That is why the outline of bilateral anatomical structures may be seen on lateral cephalograms, which makes its proper analysis difficult. ${ }^{1-3}$

There are three basic cephalometric radiological projections: lateral (left side of the head facing the sensor, Frankfort plane parallel to the floor), posteroanterior (PA) and axial (submentovertex; SMV). The most common projection in dentistry is the lateral one. Some cephalometric analyses use posteroanterior projection as well (e.g. Ricketts' summary descriptive analysis). ${ }^{2-4}$ kraniometrycznych w celu uzyskania szeregu pomiarów czaszki pacjenta. Każda z analiz posiada własny klucz interpretacyjny oraz możliwy zakres odchyleń. Rutynowo stosowane są analizy Rickettsa, McNamary, Björka, Jarabka $\mathrm{i}$ inne. ${ }^{1,3,4}$

Podstawowym narzędziem cefalometrii jest radiografia cefalometryczna, która wprowadzona została w 1934 roku przez Hofratha i Broadbenta. Radiologiczne zdjęcia cefalometryczne wymagają precyzyjnego usytuowania pacjenta względem aparatury rentgenowskiej. Służy do tego cefalostat zbudowany z oliwek usznych i wspornika nosowego. Oliwki umieszczane są w otworach słuchowych zewnętrznych. Posiadają elementy cieniujące pomagające ocenić czy głowa badanego znajduje się w prawidłowej pozycji względem źródła promieniowania. Wspornik nosowy stabilizuje głowę podczas ekspozycji. Może on zostać wyposażony w cieniującą podziałkę milimetrową umożliwiającą wykonywanie pomiarów liniowych. Stosowanie cefalostatu umożliwia analizę porównawczą wykonywanych zdjęć. Zapewnia także stały dla danego aparatu rentgenowskiego współczynnik powiększenia obrazu (od 5 do 10\%). Brak równoległości wiązki promieniowania (rozbieżne prostoliniowe tory fotonów) powoduje, iż obrazowane elementy usytuowane blisko detektora promieniowania charakteryzują się niewielkim powiększeniem. Dla obiektów oddalonych od rejestratora powiększenie może sięgać 20\%. Stąd wielokrotnie widoczny na cefalogramach bocznych głowy zdublowany zarys struktur anatomicznych utrudniający ich analizę. ${ }^{1-3}$

Zdjęcia cefalometryczne wykonywane mogą być w trzech projekcjach: bocznej (tzw. tele-boczna; pacjent zwrócony lewym bokiem do detektora promieniowania, płaszczyzna frankfurcka równoległa do podłogi), tylno-przedniej (posterior-anterior; PA) oraz osiowej (podbródkowo-ciemieniowej; SMV). Najczęściej stosowaną w stomatologii jest projekcja boczna. Niektóre metody analiz cefalometrycznych 


\section{Aim}

The aim of the study was to present the clinical purpose and validity of cephalometry in prosthetic dentistry on the basis of literature review.

\section{Material and methods}

Literature review was carried out from August to October 2018 using PubMed search engine with MeSH terms: cephalometry, prosthodontics, dental prostheses, occlusion, vertical dimension of occlusion and occlusal plane. Search parameters were constructed in order to present the most accurate view on cephalometry clinical application using norms commonly known in Polish dentistry. A total of 147 English language publications were analysed. Eventually, 18 original articles, 1 literature review and also 12 specialist studies not meeting the search criteria were qualified.

\section{Results}

Cephalometry has been a diagnostic dental tool for more than 70 years. ${ }^{5,6}$ It is possible to use cephalometric analysis to assess the orientation of the occlusal plane, ${ }^{7-11}$ anterior teeth positioning, facial type analysis and the determination of vertical dimension of occlusion, anterior and posterior guidance as well as soft tissue profile. ${ }^{4,12-22}$

The starting point of each prosthetic treatment is to determine and record the three-dimensional position of the mandible in relation to the maxilla. It refers not only wykorzystują także projekcję tylno-przednią (np. analiza cefalometryczna Rickettsa). ${ }^{2-4}$

\section{Cel pracy}

Celem pracy było przedstawienie klinicznego zastosowania cefalometrii i ocena zasadności jej stosowania w protetyce stomatologicznej w oparciu o przegląd piśmiennictwa.

\section{Material i metody}

Przeprowadzono przegląd piśmiennictwa w okresie sierpień-październik 2018. Wykorzystano do tego celu zasoby wyszukiwarki PubMed. W kryteriach wyszukiwania użyto słów kluczowych wg MeSH Terms: cephalometry, prosthodontics, dental prostheses, occlusion, vertical dimension of occlusion $i$ occlusal plane. Kryterium doboru uwzględnionych publikacji miało na celu jak najdokładniejsze przedstawienie postępowania klinicznego w oparciu o normy cefalometryczne powszechnie znane i stosowane w polskiej stomatologii. Przeanalizowano artykuły anglojęzyczne w liczbie 147. W publikacji cytuje się 18 prac oryginalnych, 1 przegląd piśmiennictwa, a także 12 opracowań specjalistycznych nie ujętych powyższą formułą wyszukiwania.

\section{Wyniki}

Cefalometria stosowana jest $\mathrm{w}$ protetyce stomatologicznej od ponad 70 lat. ${ }^{5,6}$ Metoda ta wykorzystywana jest m.in. do określania przebiegu płaszczyzny protetycznej, ${ }^{7-11}$ wyznaczania pionowego wymiaru zwarcia (ang. vertical dimension of occlusion- VDO), ${ }^{12-18}$ pozycjonowania zębów przednich, ${ }^{19,20}$ wyznaczania kąta prowadzenia stawowego i siecznego, analizy kształtu twarzy oraz profilu tkanek miękkich pacjenta. ${ }^{4,20,21,22}$

Punktem wyjściowym leczenia protetycznego jest przestrzenne określenie i zarejestrowanie 
to the position of the condyle relative to the glenoid fossa but to the vertical dimension of occlusion (VDO) as well. The foregoing procedures are particularly demanding to carry out in edentulous patients. As far as the therapeutic condyle to the fossa relation is scientifically proven, the VDO requires subsequent studies. ${ }^{23-25} \mathrm{In}$ order to estimate the ideal vertical dimension of occlusion for edentulous patients, Alhajj et al. ${ }^{18}$ suggested the "cephalometric approach" preextraction method. The first cephalometric X-ray is taken before the extraction, provided the dentate patient has got stable occlusion and proper VDO. The second film is obtained with time gap after the extraction with occlusal rims in vivo. Comparison of both radiographs helps with accurate wax rims adjustment. Many researchers have questioned the effectiveness of this procedure and recommend that it should be used alongside other diagnostic methods.

Crabtree et al. ${ }^{21}$ propose to construct patient's preextraction tissue template in the following steps. To trace the soft tissue profile using lateral preextraction cephalogram first. Next to transfer it to the stiff cardboard using carbon paper, and to cut it out using sharp scissors. The inherent radiographic technique errors are corrected by adjusting the template sectioning and stapling it along patient's real soft tissue profile. In this case a clinician may easily store the preextraction data such as vertical dimension of the occlusion and soft tissue profile measured in a midsagittal plane. Moreover, the authors recommend tracing additional landmarks such as occlusal plane line, maxillary central mesial incisor point or incisors inclination mark on the template. A clinician may refer to the preextraction template during VDO reconstruction. In conclusion, the authors emphasise the value of this profile-recording method; they stress, położenia żuchwy względem szczęki. Dotyczy to zarówno pozycji kłykcia w panewce stawu skroniowo-żuchwowego jak i pionowego wymiaru zwarcia (ang. vertical dimension of occlusion; VDO). Są to czynności szczególnie wymagające i trudne u pacjentów bezzębnych. O ile terapeutyczne położenie głów żuchwy w dole stawu skroniowo-żuchwowego jest pojęciem naukowo zbadanym i udowodnionym, o tyle wyznaczenie komponenty pionowej zwarcia $\mathrm{w}$ dalszym ciągu przysparza badaczom problemów. ${ }^{23-25}$ Pomocna może się w tym wypadku okazać metoda przedstawiona przez Alhajja i wsp. ${ }^{18} \mathrm{U}$ pacjenta bez objawów zaburzeń zwarciowo-artykulacyjnych, którego uzębienie resztkowe stanowi pełnowartościową strefę podparcia zwarciowego wykonywane jest przedekstrakcyjne zdjęcie cefalometryczne. Drugie zdjęcie wykonywane jest w pewnym odstępie czasu po ekstrakcji, w trakcie ustalania zwarcia centralnego do nowych protez. Obydwa zdjęcia są porównywane, a wzorniki koryguje się w celu jak najdokładniejszego odwzorowania pionowego wymiaru zwarcia zarejestrowanego na zdjęciu sprzed ekstrakcji. Wielu badaczy poddaje pod wątpliwość skuteczność opisanego tu postępowania i zaleca, aby było ono stosowane wspólnie z innymi metodami diagnostycznymi. Crabtree i wsp. ${ }^{21}$ po wykonaniu cefalogramu przedekstrakcyjnego proponują obrysować profil tkanek miękkich, przenieść go przy użyciu kalki na kartonowy szablon, a następnie wyciąć go przy pomocy nożyczek. Nieodłączne zniekształcenie obrazu radiologicznego względem tkanek pacjenta korygowane jest poprzez rozczłonkowanie szablonu, dopasowanie go do kształtu twarzy w linii pośrodkowej i zespolenie jego fragmentów przy pomocy zszywacza. W takim wypadku klinicysta posiada przedekstrakcyjne dane dotyczące pionowej komponenty zwarcia i profilu tkanek w płaszczyźnie pośrodkowej. Ponadto autorzy polecają wykreślić na takim szablonie linię równoległą do płaszczyzny okluzji, 
however, that it has to be supplemented with other preextraction data such as photographs, radiographs or diagnostic casts.

Orthlieb et al. ${ }^{5}$ presented the positive correlation coefficient with high dispersion coefficient between the mandibular angle measured in Gonion and the lower facial height measured by ANS-Go-ChinPt angle, based on 505 cephalometric analyses of Austrian patients. Due to musculoskeletal impact on the mandible growth and cephalometric tracing inaccuracy, the authors suggest calculating VDO estimations on the basis of two measurements of the mandibular shape (gonial angle and mandibular arch at $\mathrm{Xi}$ point) using two regression formulae presented in the paper. If both results show similar trend they become a hint for the clinician in determining vertical dimension of the occlusion. In conclusion, the authors claim that there is still no scientifically proven lower facial height estimation method. They suggest relying on the patient's subjective vertical comfort range as determined by the musculo-skeletal structure.

Tavano et al. ${ }^{16}$ presented their own cephalometric analysis system based on geometric relationships recorded on 31 lateral cephalograms of dentate adult subjects. The method includes the setting of five points, six lines and three gnathometric angles: upper (UA), transferred (TLA) and middle (MA) ones. The authors proved that there was no statistically significant difference between UA and MA values among all examined dentate patients cephalograms, which revealed the parallelism of CF-ENA and Goc-Me planes. Basing on the Thales of Miletus theorem they claimed that it is possible to estimate primordial VDO aiming at CF-ENA and Goc-Me planes parallelism and equal UA, TLA, MA angles quantity. zaznaczyć pozycję punktu siecznego siekacza przyśrodkowego szczęki, umożliwiającą jego rekonstrukcję podczas odbudowy protetycznej. Po ekstrakcji, w trakcie wykonywania uzupełnień protetycznych, klinicysta może odnieść się do stworzonego na podstawie zdjęcia cefalometrycznego szablonu. W podsumowaniu podkreślają wartość przedekstrakcyjnej rejestracji profilu pacjenta zaznaczając jednocześnie, iż nie powinna być ona metodą stosowaną arbitralnie. Polecają uwzględnienie pozostałych danych przedekstrakcyjnych, takich jak fotografie, modele diagnostyczne oraz zdjęcia radiologiczne innego rodzaju.

Orthlieb i wsp. ${ }^{5}$ opierając się na analizie cefalometrycznej 505 pacjentów narodowości austriackiej, przedstawili dodatni współczynnik korelacji z jednocześnie wysokim współczynnikiem rozproszenia dla wartości kąta żuchwy mierzonego w punkcie Gonion, a dolną wysokością twarzy mierzoną kątem zawartym między ANS-Go, a Go-ChinPt. Jednocześnie powołując się na mięśniowo-szkieletową modulację wzrostu żuchwy oraz niedokładności pomiarów cefalometrycznych sugerują, aby dla określenia wartości pionowego wymiaru zwarcia stosować równolegle regresje statystyczne oparte o dwa pomiary kształtu żuchwy (kąt o wierzchołku w punkcie Gonial oraz łuk żuchwy mierzony w punkcie Xi). Wzory formuł regresyjnych podają w opracowaniu. Jeżeli oba wyniki wykazują podobną tendencję stają się wówczas dla klinicysty wskazówką co do kierunku ustalenia VDO. We wnioskach podają, iż brak jest arbitralnej metody wyznaczania pionowego wymiaru zwarcia. Przedstawiona w opracowaniu metodologia może jedynie sugerować kierunek leczenia protetycznego. W ustalaniu wysokości zwarciowej polecają odnieść się również do subiektywnego odczucia komfortu zwarciowego pacjenta determinowanego przez jego układ mięśniowo-szkieletowy.

Tavano i wsp. ${ }^{16}$ przedstawili własny wzór analizy cefalometrycznej. Oparta o zależności 
Yamashita et al. ${ }^{15}$ studied the material consisting of 58 lateral cephalograms of the Japanese with a mean age of 28.6 years with complete natural dentition. The authors proposed an individual method of Ricketts' Lower Facial Height angle prediction (formed by the intersection between ANS-Xi and Xi$\mathrm{PM}$ lines with top of the angle at the geometric centre of the mandibular ramus). LFH clinical value is 45 degrees with a variation of $4^{\circ}$. Other angles and linear measurements not subjected to VDO changes were also analysed. Next, the multiple linear regression analysis was used to develop a LFH prediction formula, which is presented in conclusion. The authors emphasise that the presented calculation model, even if limited to one racial group, is valid in every studied LFH range, and may be applicable to patients in whom the vertical dimension of occlusion greatly deviates from average values.

In a study by Sheppard and Sheppard,,${ }^{14}$ fifty subjects with the average 10-year complete dentures wearing period were examined with the use of cephalometric radiographs. Diagnostic procedure consisted of seven lateral radiographs: three films made in the rest position without dentures approximately one minute apart, one film made with the dentures in centric occlusion and three films made in rest position with the dentures in place approximately one minute apart. Distances between maxillary anterior ridge and hard tissue Menton landmark and between two facial lead markers attached to Pogonion and Pronasale were measured. The results revealed that the mandible rest position is not stable or repeatable. Its position changes even during the sequence of three radiographs taken one minute apart. The next observation was that the mandible rest position without dentures and upon dentures insertion differs significantly. Moreover, the geometryczne metoda przewiduje wyznaczenie pięciu punktów, sześciu linii i trzech kątów gnatometrycznych: górnego (UA), transferowego (TLA) i środkowego (MA). Wartości kątów UA i MA poddane opracowaniu statystycznemu nie wykazały istotnych różnic. Udowodniło to równoległość płaszczyzn CFENA oraz Goc-Me w przedstawionym materiale badawczym obejmującym 31 cefalogramów bocznych uzębionych osób dorosłych. W oparciu o twierdzenie Talesa z Miletu autorzy stwierdzili, iż u pacjentów z zaburzonym pionowym wymiarem zwarcia możliwe jest wyznaczenie jego pierwotnej wartości w taki sposób, aby dążyć do równoległości płaszczyzn CF-ENA i Goc-Me, a tym samym równych wartości kątów UA, TLA i MA.

Yamashita i wsp. ${ }^{15}$ poddali badaniu w pełni uzębionych 58 Japończyków dla których próbowali ustalić indywidualną metodę obliczania wartości kąta dolnego piętra twarzy wg Rickettsa, tj. LFH (kąt zawarty między płaszczyznami ANS-Xi oraz Xi-PM, z wierzchołkiem w geometrycznym środku gałęzi żuchwy). Przyjęta dla tego kąta norma to $45^{\circ}$ z możliwością odchylenia klinicznego na poziomie $4^{\circ}$. Oprócz LFH autorzy poddali analizie wartości kątowe i liniowe nie podlegające wpływom zmian VDO. Następnie przeprowadzili analizę regresyjną w celu określenia zależności statystycznej tych pomiarów względem LFH. We wnioskach swojej pracy podają złożony wzór na obliczenie indywidualnej wartości LFH w oparciu o pozostałe pomiary cefalometryczne. Jak podają badacze metoda ta mimo ograniczenia do jednej grupy rasowej może być stosowana u pacjentów ze znacznymi odchyleniami pionowego wymiaru twarzy ponieważ bazuje na pomiarach indywidualnych.

W opracowaniu Sheppard i Sheppard ${ }^{14}$ analizie cefalometrycznej poddanych zostało 50 pacjentów użytkujących protezy całkowite średnio od 10 lat. U każdego badanego wykonano siedem zdjęć cefalometrycznych. Trzy 
mandible rest position in edentulous patients with dentures measured between hard tissue landmarks was more constant than in the case of patients without dentures. What is more, the skeletal surveys showed more recurrent values than measurements made between soft tissue markers. Researchers suggest that edentulous mandible rest position should not be treated as a prosthetic reconstruction starting point. Mandible equipped with occlusal wax rims or previously used prostheses would enable obtaining a more accurate vertical rest dimension during treatment.

Bassi et al. ${ }^{7}$ examined the use of cephalometry in occlusal plane positioning during complete denture fabrication. Each of forty-two Caucasian patients (mean age 65 years) was rehabilitated with the denture set constructed with the use of a conventional wax rims method. After one-month adaptation phase, the Camper plane was marked with radiopaque discs attached extraorally and the lateral cephalograms with prostheses in vivo were taken. The Steiner analysis was traced. Statistical analysis based on four gnathometric angles revealed that complete dentures constructed in a conventional way showed lower VDO, anterorotation of the occlusal plane and the prevalence of the maxillary denture in the subdivision of the denture space according to the cephalometric norms. In discussion, the authors do not recommend using cephalometry in positioning the posterior teeth in complete denture manufacturing.

The same research group was diagnosed by means of cephalometrics following the Ricketts' design in order to assess anterior teeth positioning in complete dentures. ${ }^{20}$ Distances A1/A-Pog, B2/A-Pog and angulation of the mandibular and maxillary median incisors long axes relative to A-Pog plane were measured. w pozycji spoczynkowej bez protez, jedno w zwarciu centralnym z protezami, trzy w pozycji spoczynkowej z protezami. Zdjęcia w położeniu spoczynkowym żuchwy wykonywane były w odstępie około jednej minuty. Dokonano na nich pomiarów liniowych między przednią krawędzią wyrostka zębodołowego szczęki i kostnym punktem Menton, a także między cieniującymi znacznikami tkanek miękkich w punktach Pogonion i Pronasale. Analiza ww. pomiarów wykazała, że żuchwa utrzymywana przez pacjenta w pozycji spoczynkowej nie wykazuje jednoznacznego i powtarzalnego położenia. Jej usytuowanie zmienia się nawet w czasie wykonania serii trzech zdjęć cefalometrycznych. Do kolejnej obserwacji zaliczyli fakt, że położenie spoczynkowe bez założonych protez oraz po ich założeniu różni się w sposób jednoznaczny. Stąd przyjmowanie położenia spoczynkowego u bezzębnych jako pozycji wyjściowej przy ustalaniu zwarcia w metodzie anatomofizjologicznej obarczone może być dużym błędem pomiarowym. W podsumowaniu stwierdzają, że mierzona pomiędzy punktami kostnymi pozycja spoczynkowa żuchwy pacjentów z założonymi protezami była bardziej powtarzalna, niż w przypadku pacjentów bez protez. Co więcej, pomiary szkieletowe wykazywały większą powtarzalność nad pomiarami przeprowadzanymi pomiędzy znacznikami tkanek miękkich. Autorzy na bazie analizy cefalogramów bocznych sugerują, aby ustalając pionową komponentę zwarcia kierować się położeniem spoczynkowym żuchwy kiedy w ustach znajdują się stare protezy pacjenta bądź wzorniki zwarciowe dla protez nowo wykonywanych.

Bassi i wsp. ${ }^{7}$ przeprowadzili badanie nad zastosowaniem cefalometrii $\mathrm{w}$ wyznaczaniu płaszczyzny okluzyjnej podczas wykonawstwa całkowitych protez osiadających. W tym celu każdemu z 42 pacjentów rasy Kaukaskiej wykonano komplet protez. Średni wiek badanych wynosił 65 lat. Uzupełnienia zostały wykonane metodą zbliżoną do anatomofizjologicznej 
According to the authors' results, the wax rims denture fabrication method caused the anterior position of the maxillary and mandibular incisors, lower inclination of maxillary incisors and similar inclination of mandibular incisors according to Ricketts' mean values. After the statistical analysis the authors concluded that there is no scientifically proven application of cephalometry for the routine anterior teeth positioning in complete denture constructing.

Rajawat et al. ${ }^{11}$ carried out the cephalometric evaluation for the correlation between Downs' occlusal plane (OP) and Camper's plane $(\mathrm{CP})$ in patients manifesting different facial types. All sixty-six subjects were classified as Mesoprosopic, Euryprosopic and Leptoprosopic which was based on the Total Facial Index (TFI) given by Martin and Saller. ${ }^{26,27}$ Before the lateral cephalograms were taken, small radiopaque steel balls had been taped to each participant (lower border of Alare to superior border of Tragus) to locate the Camper's plane. TFI, OP-CP and OP-FHP (Frankfort horizontal plane) angles were statistically analysed. In the Discussion section, the authors stated that the course of the Camper's plane gives very near cant to the occlusal plane in dentate patients, and that the shape of the face significantly impacts the course of the occlusal plane. This finding is confirmed by the study carried out by Mittal. $^{28}$ On the other hand, the finding is at variance with those of van Niekerk et al. ${ }^{29}$ and Karkazis et al., ${ }^{30}$ who did not prove the parallelism between Camper's plane and the occlusal plane. Rajawat et al. stated in Conclusions of their study that the cant of occlusal plane varies depending on the facial types and the Camper's plane, running from the lower border of Alare to the superior border of Tragus gives very near cant of natural occlusal plane within three facial types researched in the cited study. wg Spiechowicza. Po miesiącu adaptacji pacjentom zewnątrzustnie zamocowano cieniujące znaczniki określające przebieg linii Campera oraz wykonano zdjęcia cefalometryczne z protezami in vivo. Wykreślono analizę cefalometryczną wg Steinera. Analiza statystyczna przeprowadzona w oparciu o wartości 4 kątów gnatometrycznych wykazała, że protezy wykonane metodą anatomofizjologiczną, w porównaniu do norm cefalometrycznych, charakteryzowały się: obniżonym pionowym wymiarem zwarcia, anteriorotacją płaszczyzny okluzyjnej oraz przestrzenną przewagą protezy górnej w strefie neutralnej. Stąd w końcowym wniosku cytowanego opracowania, autorzy nie rekomendują posługiwania się analizą cefalometryczną w celu ustalania pozycji zębów bocznych w wykonawstwie protez całkowitych.

Ta sama grupa badawcza poddana została analizie cefalometrycznej wg Rickettsa w celu oceny usytuowania zębów przednich $\mathrm{w}$ protezach całkowitych. ${ }^{20}$ Zmierzone zostały odległości A1/A-Pog oraz B2/A-Pog oraz kąty nachylenia osi długich siekaczy przyśrodkowych względem płaszczyzny A-Pog. W wynikach autorzy podają, że usytuowane metodą anatomofizjologiczną siekacze zostały umiejscowione doprzednio, a osie dhugie siekaczy w szczęce wykazywały mniejszą wartość kąta inklinacji względem norm Rickettsa. Osie długie siekaczy w żuchwie umiejscowione były niemal zgodnie z wytycznymi cefalometrycznymi. Po przeprowadzeniu analizy statystycznej autorzy stwierdzili, że nie ma jednoznacznego i udowodnionego naukowo zastosowania cefalometrii w umiejscawianiu zębów przednich w protezach całkowitych.

Analiza cefalometryczna posłużyła także jako narzędzie badawcze do określenia relacji przebiegu płaszczyzny okluzyjnej Downsa (OP) względem linii Campera (CP) u pacjentów o różnym kształcie twarzy.

W badaniu Rajawata i wsp. ${ }^{11} 66$ pacjentom wyliczono wskaźnik morfologiczny (TFI) wg 
Qamar et al. ${ }^{31}$ presented interesting results in the middle and lower thirds of the face height ratio based on Ricketts' analysis method. The research group included twenty edentulous Pakistani patients for whom new complete dentures were fabricated. First, lateral cephalograms were taken prior to the second films taken after the dentures insertion. Ricketts analysis was employed to measure hard tissues, and Burstone analysis was used to evaluate the soft ones. In the Results, the stable proportion of 0.8 (with the deviation of 0.2 ) was presented between the middle and the lower facial height measured skeletally (N-ANS and ANS-hard tissue Menton). Moreover, the soft tissue landmark lengths between Glabella-Subnasale and Subnasale-soft tissue Menton obtained the proportion near 1. No significant differences in values of the foregoing ratios were observed in patients with and without dentures in the abovementioned study.

\section{Summary}

Cephalometry is a non-invasive research tool widely used in prosthetic dentistry. The researchers presented in this review demonstrate its usefulness before, during and after the prosthetic treatment. As yet, the multiplicity of cephalometric analysis methods and small research groups offer no chance for creating the universal cephalometry usage model for the treatment of prosthetic patients. The use of cephalometry in prosthetic dentistry requires further research, which may contribute to making this tool a routine one in the clinical treatment of prosthetic patients. wzoru Garsona, a następnie badanych przydzielono do grupy o twarzy szerokiej, średniej lub wąskiej zgodnie z wytycznymi Martina i Sallera. ${ }^{26,27}$ Przed badaniem radiologicznym, w miejscach dolnego brzegu skrzydeł nosa oraz górnej krawędzi skrawka ucha przyklejono cieniujące wskaźniki dzięki którym możliwe było wykreślenie linii Campera (CP). Analizie statystycznej poddane zostały wartości wskaźnika TFI, kątów OP-FHP i OP-CP. W dyskusji autorzy stwierdzają, że u pacjentów z naturalnym uzębieniem przebieg linii Campera zbliżony jest do przebiegu płaszczyzny zwarciowej oraz że kształt twarzy ma istotny wpływ na przebieg płaszczyzny okluzyjnej. Wnioski te pozostają w zgodzie z badaniami Mittal. ${ }^{28} \mathrm{Z}$ drugiej zaś strony stoją w opozycji do opracowań van Niekerk i wsp. ${ }^{29}$ oraz Karkazis i wsp.,${ }^{30}$ którzy nie udowodnili jednoznacznej równoległości między linią Campera i płaszczyzną protetyczną. Rajawat i wsp. w cytowanym tu opracowaniu stwierdzają, iż przebieg płaszczyzny okluzyjnej zmienia się w zależności od kształtu twarzy oraz że linia nosowo-uszna poprowadzona od dolnego brzegu skrzydełka nosa do górnego brzegu skrawka ucha pozostaje tożsama z przebiegiem naturalnej płaszczyzny zwarciowej dla trzech badanych tu grup pacjentów.

Qamar i wsp. ${ }^{31}$ opierając swoje badania o analizę cefalometryczną wg Rickettsa, uzyskali interesujące rezultaty $\mathrm{w}$ aspekcie proporcji wysokości środkowego i dolnego piętra twarzy. Grupa badawcza liczyła 20 bezzębnych Pakistańczyków użytkujących protezy całkowite osiadające. Każdemu z badanych wykonano jedno zdjęcie cefalometryczne bez protez i drugie zdjęcie z protezami. Na radiogramach ocenie poddane zostały tkanki twarde (analiza Rickettsa) i miękkie (analiza Burstone'a). Badacze w uzyskanych wynikach podają, że proporcje szkieletowe środkowego do dolnego piętra twarzy mierzone poprzez zrzutowanie punktów N, ANS i kostnego Menton na płaszczyznę wertykalną tworzą odcinki pozostające 
ze sobą w proporcji 0,8 (z możliwym odchyleniem 0,2). Co więcej, odcinki mierzone poprzez zrzutowanie punktów skórnych Glabella, Subnasale i Menton na płaszczyznę wertykalną wykazują stosunek długości zbliżony do 1 . Obydwa stosunki nie ulegały wyraźnym zmianom na zdjęciach cefalometrycznych przed i po założeniu protez przez opisywanych tu pacjentów.

\section{Podsumowanie}

Cefalometria jest nieinwazyjnym narzędziem badawczym szeroko wykorzystywanym w protetyce stomatologicznej. Autorzy cytowanych opracowań wykazują celowość jej stosowania $\mathrm{w}$ analizie przedprotetycznej, $\mathrm{w}$ trakcie prowadzonego leczenia, a także po jego zakończeniu. Mnogość rodzajów analiz cefalometrycznych oraz niewielkie rozmiary grup badawczych powodują, iż obecnie nie sposób jest przedstawić uniwersalny wzorzec zastosowania tego badania dla szerokiego grona pacjentów protetycznych. Dlatego wykorzystanie cefalometrii $\mathrm{w}$ protetyce stomatologicznej wymaga prowadzenia dalszych badań, które umożliwią rutynową diagnostykę i leczenie przy pomocy tej metody.

\section{References / Piśmiennictwo}

1. Proffit WR, Fields HW, Sarver DM: Ortodoncja współczesna. Elsevier U\&P, Wrocław 2009.

2. Visser H, Rödig T, Hermann KP: Dose reduction by direct-digital cephalometric radiography. Angle Orthod 2001; 71(3): 159163.

3. Różyło-Kalinowska I, Różyło TK: Współczesna radiologia stomatologiczna. Czelej, Lublin 2012.

4. Jacobson A, Jacobson RL: Radiographic cephalometry. Quintessence Publishing, 2006.

5. Orthlieb JD, Laurent $M$, Laplanche $O$ : Cephalometric estimation of vertical dimension of occlusion. J Oral Rehabil 2000; 27(9): 802-807.

6. Edwards CL, Richards MW, Billy EJ, Neilans $L C$ : Using computerized cephalometrics to analyse vertical dimension od occlusion. Int $\mathrm{J}$ Prosthodont 1993; 6(4): 371-376.

7. Bassi F, Deregibus A, Previgliano V, Bracco P, Preti G: Evaluation of the utility of cephalometric parameters in constructing complete denture. Part I: placement of posterior teeth. J Oral Rehabil 2001; 28(3): 234-238.
8. Douglas JR, Maritano FR: Open rest, a new concept in the selection of the vertical dimension of occlusion. J Prosthet Dent 1965; 15(5): 850-856.

9. Kumar S, Garg S, Gupta S: A determination of occlusal plane comparing different levels of the tragus to form ala-tragal line or Camper's line: a photographic study. J Adv Prosthodont 2013; 5(1): 9-15.

10. Quran AL, Hazza'a A, Nahass N: The position of the occlusal plane in natural and artifical dentitions as related to other craniofacial planes. J Prosthodont 2010; 19(8): 601-605.

11. Rajawat I, Venkataramana V, Patil P, Guram G, Gupta N, Lau M, Thakkar P, Shah D, Kaur RK: A cephalometric evaluation for corelation of different facial types with occlusal plane in dentulous and edentulous patients. Oral Health and Dent Manag 2014; 13(4): 1188-1191.

12. Ferro KJ: Glossary of Prosthodontic Terms Edition 9. J Prosthet Dent 2017; 117(5S): e1e105.

13. Strajnic L, Stanisic-Sinobad D, Markovic D, Stojanovic L: Cephalometric indicators of the 
vertical dimension of occlusion. Coll Antropol 2008; 32(2): 535-541.

14. Sheppard IM, Sheppard SM: Vertical dimension measurements. J Prosthet Dent 2006; 95(3): 175-180.

15. Yamashita S, Shimizu M, Katada H: A newly proposed method to predict optimum occlusal vertical dimension. J Prosthodont 2015; 24(4): 287-290.

16. Tavano KTA, Seraidarian PI, de Oliveira $D D$, Jansen $W C$ : Determination of vertical dimension of occlusion in dentate patients by cephalometric analysis - pilot study. Gerodont 2012; 29(2): e297-e305.

17. Alhajj MN, Daer AA: A proposed linear skeletal distance to predict occlusal vertical dimension: a cephalometric study. J Prosthet Dent 2017; 118(6): 732-735.

18. Alhajj MN, Khalifa N, Abudo J, Amran AG: Determination of occlusal vertical dimension for complete dentures patients: an updated review. J Oral Rehabil 2017; 44(11): 896-907.

19. Coachman C, Calamita MA, Coachman FG, Coachman $R G$, Sesma N: Facially generated and cephalometric guided 3D digital design for complete mouth implant rehabilitation: A clinical report. J Prosthet Dent 2017; 117(5): 577-586.

20. Bassi F, Rizzatti A, Schierano G, Preti G: Evaluation of the utility of cephalometric parameters in constructing complete denture. Part II: placement of anterior teeth. J Oral Rehabil 2001; 28(4): 349-353.

21. Crabtree DG, Ward JE, McCasland JP: A preextraction profile record. J Prosthet Dent 1981; 45(5): 479-483.

22. Reyneke JP, Ferretti C: Kliniczna ocena este- tyki twarzy. Stom Estetycz 2012; 8(4): 224239.

23. Racich M: Podstawowe zasady okluzji. Czelej, Lublin 2018.

24. Dawson PE: From TMJ to smile design. Mosby Elsevier, St.Louis 2007.

25. Okeson JP: Management of temporomandibular disorders and occlusion. Mosby Elsevier, St.Louis 2013.

26. Rexhepi A, Meka V: Cephalofacial morphological characteristic of Albanian Kosova population. Int J Morpholo 2008; 26: 935-940.

27. Singh P, Purkait R: A cephalometric study among subaste groups Dangi and Ahirwar of Khurai Block of Madhya Pradesh. Antropology 2006; 8(3): 215-217.

28. Mittal R: Comparison of the occlusal plane in dentulous and edentulous patients: a cephalometric study. J Ind Prosthod Soc 2008; 8(4): 195-200.

29. Van Niekerk FW, Miller VJ, Bibby RE: The ala-tragus line in complete denture prosthodontics. J Prosthet Dent 1985; 53: 6769.

30. Karkazis HC, Polyzois GL: Cephalometrically predicted occlusal plane: implications in removable. J Prosthet Dent 1991; 65: 258264.

31. Qamar K, Munir U, Naeem S: Role of cephalometry in evaluation of vertical dimension. Pak O Dent J 2013; 33(1): 183-186.

Zaakceptowano do druku: 15.11.2018 r.

Adres autorów: 85-220 Bydgoszcz, ul. Czarna Droga 11/49.

C Zarząd Główny PTS 2019. 